\title{
PENGARUH KUALITAS PRODUK DAN BRAND IMAGE \\ TERHADAP KEPUTUSAN PEMBELIAN
}

(Studi pada Mahasiswa Pengguna Produk Sepatu Merek Converse di Fisip Universitas Merdeka Malang)

\author{
Supriyadi, Wahyu Wiyani, Ginanjar Indra K.N \\ Program Studi Admnistrasi Bisnis \\ Fakultas Ilmu Sosial dan Ilmu Politik \\ Universitas Merdeka Malang
}

\begin{abstract}
This study aimed to describe (1) If the variable influence on product quality product purchasing decisions Converse brand shoes. (2) Whether variables affect the brand image of the product purchase decisions Converse brand shoes. (3) Is the variable product quality and brand image influence the purchasing decisions Converse brand shoes

The population in this study was students whom to be Converse brand shoes product user in Faculty of Social and Political Science at the Merdeka University of Malang, a total of 39 respondents using non-probability sampling. Data that has met the validity and reliability, and classical assumption ( $t$ test and $F$ test) is processed to produce a regression equation as follows:$$
\mathrm{Y}=13,789+-0,261 \mathrm{X} 1+0,689 \mathrm{X} 2
$$

Where the purchasing decisions variable $(Y)$, the qulity of the product $(X 1)$, and brand image (X2). Hypothesis testing using $t$ test showed that the variable quality of the products that have been researched proved no effect on the purchasing decisions, but the variables that proved influential brand image on consumers purchasing decisions. Hypothesis testing using the $F$ test shows that the variable quality of the product and brand image influence on purchase decisions by 22, 7\%, while the remaining 77, 3\% is influenced by variables that are not used in this study.
\end{abstract}

\section{Keywords: Quality Product, Brand Image, Purchasing Decision}

\begin{abstract}
Abstrak: Penelitian ini bertujuan untuk mendeskripsikan (1) Jika pengaruh variabel pada produk kualitas produk keputusan pembelian Converse merek sepatu. (2) Keduanya, variabel mempengaruhi citra merek dari keputusan pembelian produk Converse merek sepatu. (3) Apakah variabel kualitas produk dan citra merek mempengaruhi keputusan pembelian Converse merek sepatu

Populasi dalam penelitian ini adalah siswa merek sepatu pengguna produk Converse di Fakultas Ilmu Sosial dan Politik di Universitas Merdeka Malang, sebanyak 39 responden dengan menggunakan non-probability sampling. Data yang telah memenuhi validitas dan reliabilitas, dan asumsi klasik (uji t dan uji F) diproses untuk menghasilkan persamaan regresi sebagai berikut:

$\mathrm{Y}=13.789+-0261 \mathrm{X} 1+0.689 \mathrm{X} 2$

Dimana keputusan pembelian variabel (Y), kualitas pelayanan dari produk (X1), dan citra merek (X2). Pengujian hipotesis menggunakan uji $\mathrm{t}$ menunjukkan bahwa kualitas pelayanan variabel dari produk yang telah diteliti terbukti tidak berpengaruh pada keputusan pembelian, tetapi variabel yang terbukti brand image berpengaruh pada konsumen keputusan pembelian. pengujian hipotesis menggunakan uji $\mathrm{F}$ menunjukkan bahwa variabel kualitas produk dan merek pengaruh citra terhadap keputusan pembelian oleh $22,7 \%$, sedangkan remaning $77,3 \%$ dipengaruhi oleh variabel yang tidak digunakan dalam penelitian ini.
\end{abstract}

Kata Kunci :Kualitas Produk, Citra Merek, Kepurusan Pembelian 
Semakin beraneka ragam merek-merek produk sepatu yang beredar di pasaran, hal tersebut mendorong konsumen untuk lebih pintar dan lebih cermat lagi dalam memutuskan pemilihan produk sepatu yang diharapkan, karena pada umumnya merek sangat berpengaruh terhadap keputusan pembelian konsumen. Konsumen beranggapan bahwa merek yang terkenal di pasaran lebih bagus dan lebih berkualitas dibandingkan dengan merek yang kurang populer di pasaran, karena merek yang populer di pasaran memberikan informasi yang lengkap dibandingkan produk dengan merek yang cenderung tertinggal di pasaran, maka dengan adanya merek, konsumen dapat dengan mudah untuk membedakan karakteristik dari tiap-tiap produk yang bermunculan di pasaran, dan perusahaan juga memerlukan informasi tentang faktor-faktor yang dapat mempengaruhi konsumen dalam melakukan keputusan pembelian suatu produk, diantaranya faktor yang turut berperan dalam pengambilan keputusan pembelian konsumen seperti kualitas produk (product quality) dan citra merek (brand image) suatu produk.

Kualitas produk (product quality) yang dimaksud merupakan pemahaman bahwa produk yang ditawarkan oleh perusahaan mempunyai nilai jual lebih yang tidak dimiliki oleh produk pesaing, maka dari itu perusahaan berusaha memfokuskan pada kualitas produknya, dan membandingkannya dengan produk yang ditawarkan oleh perusahaan pesaing. Produk dengan penampilan terbaik belum tentu merupakan produk dengan kualitas tertinggi, jika tampilannya bukanlah yang dibutuhkan dan diinginkan oleh konsumen dan pasar, oleh karena itu produk-produk produsen yang sudah ada di pasaran saat ini dituntut untuk lebih kreatif dan memperbanyak variasi serta inovasi produknya sesuai kebutuhan konsumen dan pasar, sedangkan citra merek (brand image) suatu produk merupakan representasi dari keseluruhan persepsi terhadap merek dan dibentuk dari informasi dan pengalaman masa lalu terhadap merek itu. Pengaruh citra merek suatu produk berhubungan dengan keyakinan dan preferensi konsumen terhadap suatu merek produk. Konsumen yang memiliki citra positif terhadap suatu merek tertentu, akan lebih memungkinkan konsumen tersebut untuk melakukan pembelian ulang dari produkproduk yang dihasilkan dari merek perusahaan tersebut. Variabel-variabel yang dapat mempengaruhi konsumen dalam melakukan keputusan pembelian suatu produk, diantaranya adalah seperti dari kualitas produk dan citra merek (brand image) suatu produk, sehingga konsumen akan tetap loyal terhadap produkproduk yang dihasilkan oleh perusahaan tersebut.

Kelebihan sepatu Converse yang cocok digunakan dalam berbagai suasana dan cocok dipadupadankan dengan berbagai macam gaya membuat Converse mampu mempertahankan pangsa pasarnya sampai sekarang ini, bahannya yang disesuaikan dengan kontur kaki membuat kenyamanan tersendiri bagi para pemakainya. Model dan motifnya pun tidak kalah unik dan variatif mengikuti perkembangan mode sehingga membuat sepatu Converse memiliki keunggulan tersendiri dan semakin dicintai penggemarnya.

Sepatu Converse mungkin yang tertua, yang paling dicari, dan terlaris sepanjang masa, seperti yang telah diungkapkan bahwa di Amerika sedikitnya $50 \%$ dari penduduknya memiliki setidaknnya sepasang sepatu Converse, hal tersebut dikarenakan Converse merupakan perusahaan sepatu yang berbasis di Amerika, yang telah dikenal keahliannya dalam pembuatan produk sepatu olah raga dan sepatu gaya hidup, bahkan di Indonesia pun para pengusaha sepatu baik offline maupun online sudah banyak yang menjual produk sepatu Converse, hal tersebut dikarenakan dari keunggulan-keunggulan yang dimiliki sepatu Converse itu sendiri, seperti dari kulitas serta brand, yang perusahaan ketahui hal tersebut sangat mempengaruhi persepsi serta minat beli konsumen, dan pastinya sangat digandrungi khususnya oleh kawula muda.

\section{Rumusan Masalah}

1. Apakah variabel kualitas produk berpengaruh terhadap keputusan pembelian produk sepatu Converse?

2. Apakah vaiabel brand image berpengaruh terhadap keputusan pembelian produk sepatu Converse?

3. Apakah vaiabel kualitas produk dan brand image berpengaruh terhadap keputusan pembelian produk sepatu Converse?

\section{TINJAUAN PUSTAKA}

Menurut Kotler (1995:508),"Produk merupakan apa saja yang dapat ditawarkan ke pasar untuk diperhatikan, diperoleh, atau 
dikonsumsi yang dapat memenuhi keinginan dan kebutuhan".

$$
\text { Menurut Tjiptono (1999:95),“Secara }
$$

konseptual produk adalah pemahaman subyektif dari produsen atas "sesuatu" yang bisa ditawarkan sebagai usaha untuk mencapai tujuan organisasi melalui pemenuhan kebutuhan dan keinginan konsumen, sesuai dengan kompetensi dan kapasitas organisasi serta daya beli".

Menurut Kotler dan Amstrong (1995:444), "Produk adalah sesuatu yang dapat ditawarkan ke pasar untuk mendapatkan perhatian, untuk dibeli, digunakan atau dikonsumsi yang dapat memenuhi suatu keinginan atau kebutuhan".

Berbicara mengenai produk maka aspek yang perlu diperhatikan adalah kualitas produk. Kualitas produk merupakan pemahaman bahwa produk yang ditawarkan oleh penjual mempunyai nilai jual lebih yang tidak dimiliki oleh produk pesaing.

Menurut Prawirosentono (2004:6), "Kualitas produk adalah keadaan fisik, fungsi dan sifat produk bersangkutan yang dapat memenuhi selera dan kebutuhan konsumen dengan memuaskan sesuai nilai uang yang telah dikeluarkan".

Menurut Goetdch dan Davis (2002:4), "Kualitas produk merupakan suatu kondisi dinamis yang berhubungan dengan barang, jasa, manusia, produk, dan lingkungan yang memenuhi atau melebihi harapan".

\section{Dimensi Kualitas Produk}

Menurut Orville, Larreche, dan Boyd (2005: 422), “Apabila perusahaan ingin mempertahankan keunggulan kompetitifnya dalam pasar, perusahaan harus mengerti aspek dimensi apa saja yang digunakan oleh konsumen untuk membedakan produk yang dijual perusahaan tersebut dengan produk pesaing".

Menurut Kotler dan Keller (2009:8-10), ada sembilan dimensi kualitas produk seperti berikut ini:

a. Bentuk (form), meliputi ukuran, bentuk, atau struktur fisik produk.

b. Fitur (feature), karakteristik produk yang menjadi pelengkap fungsi dasar produk.

c. Kualitas kinerja (performance quality), adalah tingkat dimana karakteristik utama produk beroperasi.

d. Kesan kualitas (perceived quality) sering dibilang merupakan hasil dari penggunaan pengukuran yang dilakukan secara tidak langsung karena terdapat kemungkinan bahwa konsumen tidak mengerti atau kekurangan informasi atas produk yang bersangkutan.

e. Ketahanan (durability), ukuran umur operasi harapan produk dalam kondisi biasa atau penuh tekanan, merupakan atribut berharga untuk produk-produk tertentu.

f. Keandalan (reliability), adalah ukuran probabilitas bahwa produk tidak akan mengalami malfungsi atau gagal dalam waktu tertentu.

g. Kemudahan perbaikan (repairability), adalah ukuran kemudahan perbaikan produk ketika produk itu tak berfungsi atau gagal.

h. Gaya (style), menggambarkan penampilan dan rasa produk kepada pembeli.

i. Desain (design), adalah totalitas fitur yang mempengaruhi tampilan, rasa, dan fungsi produk berdasarkan kebutuhan pelanggan.

Berdasarkan dimensi-dimensi tersebut, dapat disimpulkan bahwa suatu dimensi kualitas merupakan syarat agar suatu nilai dari produk memungkinkan untuk bisa memuaskan pelanggan sesuai harapan.

\section{Brand Image}

Menurut American Marketing Association (AMA) dalam Kotler (1997:63),"Merek yaitu nama, istilah, tanda, simbol, atau desain atau panduan dari hal-hal tersebut yang dimaksudkan untuk memberikan identitas bagi barang atau jasa yang dibuat atau disedikan suatu penjual atau kelompok penjual serta membedakannya dari barang atau jasa yang disediakan pesaing".

Menurut America Marketing Association (AMA) dalam Kotler (2009:258),"Merek merupakan nama, istilah, tanda, simbol, atau rancangan, atau kombinasi dari semuanya, yang dimaksudkan untuk mengidentifikasi barang atau jasa penjual atau kelompok penjual dan untuk mendeferensiasikannya”.

Menurut Stanton dan Lamarto (1994:269), "Merek adalah nama, istilah, simbol, atau desain khusus, atau beberapa kombinasi unsurunsur yang dirancang untuk mengidentifikasikan barang atau jasa yang ditawarkan penjual".

Menurut Kotler (1997:63), merek merupakan suatu simbol yang kompleks yang dapat menyampaikan enam tingkat pengertian, antara lain: 
a. Atribut (Attributes), suatu merek mendatangkan atribut tertentu kedalam pikiran konsumen.

b. Manfaat (Benefits), atribut yang ada harus diterjemahkan menjadi manfaat fungsional dan emosional.

c. Nilai (Values), merek juga menyatakan suatu tentang nilai pembuat atau produsen.

d. Budaya (Culture), merek dapat merepresentasikan budaya.

e. Kepribadian (Persnality), merek dapat menjadi proyeksi dan pribadi tertentu.

f. Pengguna (User), merek dapat mengesankan tipe konsumen tertentu.

Menurut Tjiptono (2005:49), “Brand Image merupakan deskripsi tentang asosiasi dan keyakinan konsumen terhadap merek tertentu".

Brand image itu sendiri memiliki arti kepada suatu pencitraan sebuah produk dibenak konsumen secara massal. Setiap orang akan memiliki pencitraan yang sama terhadap sebuah merek. Persaingan dunia industri yang semakin ketat saat ini, menuntut perusahaan untuk lebih kretif dan membuat suatu keunggulan yang kompetitif, baik itu dari segi kemasan, produk, saluran pemasaran maupun citranya, jika tanggapan konsumen tentang penawaran suatu produk yang bersaing tetap sebagai suatu hal yang sama atau biasa, maka konsumen akan melihat merek dar suatu produk dengan tanggapan yang berbeda.

Menurut Kotler (1997:259), citra yang efektif melakukan tiga hal untuk suatu produk, yaitu:

a. Menyampaikan suatu pesan tunggal yang memantapkan karakter produk dan usulan nilai.

b. Menyampaikan pesan dengan cara yang berbeda, sehingga tidak dikelirukan dengan pesan serupa dari para pesaing.

c. Mengirimkan kekuatan emosional sehingga membangkitkan hati maupun pikiran pembeli.

Menurut Rangkuti (2002:2), merek dapat juga dibagi dalam pengertian lain, yaitu:

a. Brand Name (nama merek) yang merupakanbagian dari yang dapat diucapkan misalnya, Aqua, Honda, Indomie, Nokia dan lain sebagainya.

b. Brand Mark (tanda merek) yang merupakan bagian dari merek yang dapat dikenali namun tidak dapat diucapkan, seperti lambang, desain huruf atau warna khusus. Misalnya: symbol Daihatsu. c. Trade Mark (tanda merek dagang) yang merupakan merek atau sebagian dari merek yang dilindungi hukum, karena kemampuannya untuk menghasilkan sesuatu yang istimewa. Tanda dagang ini melindungi penjual dengan istimewaanya untuk menggunakan nama merek (tanda merek).

d. Copyright (hak cipta) yang merupakan hak istimewa yang dilindungi undang-undang untuk memproduksi, menerbitkan, dan menjual karya tulis, karya music, dan karya seni.

Berdasarkan definisi yang telah dikemukakan diatas dapat disimpulkan bahwa pengertian merek adalah janji penjual kepada konsumen secara konsisten untuk memberikan feature, manfaat, dan jasa tertentu kepada konsumen dan merek terbaik akan memberikan jaminan kualitas.

\section{Indikator Brand Image}

Indikator-indikator yang membentuk brand image menurut Aaker dan Biel (2009:71) adalah:

a. Citra pembuat (Corporate Image), yaitu sekumpulan asosiasi yang dipersepsikan konsumen terhadap perusahaan yang membuat suatu barang atau jasa. Meliputi: popularitas, kredibilitas, jaringan perusahaan, serta pemakai itu sendiri.

b. Citra produk / konsumen (product Image), yaitu sekumpulan asosiasi yang dipersepsikan konsumen terhadap suatu barang atau jasa. Meliputi: atribut dari produk, manfaat bagi konsumen, serta jaminan.

c. Citra pemakai (User Image), yaitu sekumpulan asosiasi yang dipersepsikan konsumen terhadap pemakai yang menggunakan suatu barang atau jasa. Meliputi: pemakai itu sendiri, serta status sosialnya.

Citra merek merupakan serangkaian asosiasi yang ada dalam benak konsumen terhadap suatu merek, biasanya terorganisasi menjadi suatu makna. Hubungan terhadap suatu merek akan semakin kuat jika didasarkan pada pengalaman dan mendapat banyak informasi. Citra atau asosiasi mempresentasikan persepsi yang bisa merefleksikan kenyataan yang obyektif ataupun tidak. Citra yang terbentuk dari asosiasi inilah yang mendasari dari keputusan pembelian konsumen. 
Konsumen lebih sering membeli produk dengan merek yang terkenal karena mereka merasa lebih nyaman dengan hal-hal yang sudah dikenal, dan adanya asumsi bahwa merek yang terkenal lebih dapat diandalkan, selalu tersedia dan mudah dicari, dan memiliki kualitas yang sudah tidak diragukan. Sehingga merek yang lebih dikenal lebih sering dipilih konsumen dibandingkan merek yang belum dikenal.

\section{METODE}

\section{Jenis Penelitian}

Jenis penelitian yang digunakan dalam penelitian ini adalah jenis penelitian kuantitatif.

Menurut Sugiyono (2011:13),"Metode penelitian kuantitatif dapat diartikan sebagai metode penelitian yang berlandaskan pada filsafat positivisme, digunakan untuk meneliti pada populasi atau sampel tertentu, teknik pengambilan sampel pada umumnya dilakukan secara random, pengumpulan dan menggunakan instrumen penelitian, analisis data bersifat kuantitatif/statistik dengan tujuan untuk menguji hipotesis yang telah ditetapkan".

Berdasarkan tingkat eksplanasinya atau tingkat penjelasan, maka penelitian ini adalah jenis penelitian deskriptif. Penelitian deskriptif adalah penelitian yang berusaha menggambarkan kegiatan penelitian dengan tujuan menerangkan secara sistematis terhadap bagian-bagian dan fenomena serta hubungannya dengan menggunakan model matematis, teori, dan hipotesis yang berkaitan dengan penelitian, (Sugiyono, 2012:13).

\section{Variabel Penelitian}

1. Variabel bebas yaitu variabel-variabel yang mempengaruhi variabel lain. Variabel bebas yang digunakan dalam penelitian ini adalah kualitas produk dan citra merek (brand image).

2. Variabel Terikat yaitu variabel yang dipengaruhi oleh variabel lain. Variabel terikat yang digunakan dalam penelitian ini adalah keputusan pembelian

\section{Populasi}

Menurut Sugiyono (2010:115),"Populasi merupakan wilayah generalisasi yang terdiri dari obyek/subyek yang mempunyai kualitas dan karakteristik tertentu yang ditetapkan oleh peneliti untuk dipelajari dan kemudian ditarik kesimpulannya. Populasi dalam penelitian ini adalah Mahasiswa Fakultas Ilmu Sosial dan
Ilmu Politik Universitas Merdeka Malang yang menggunakan produk sepatu dengan merek Converse sebanyak 39 orang.

\section{Teknik Analisis Data \\ 1. Uji instrumen}

a. Uji Validitas, Uji validitas digunakan untuk menguji kevalidan kuesioner.

b. Uji Reliabilitas, untuk mengukur konsistensi konstruk atau variabel penelitian, dan dalam kuesioner dikatakan reliabel jika jawaban seseorang terhadap pertanyaan adalah konsisten atau stabil dari waktu kewaktu. Suatu variabel dikatakan reliabel apabila memiliki nilai Alpha $>0,50$.

\section{Uji Asumsi Klasik \\ a. Uji Asumsi Multikolinieritas}

Pedoman model regresi yang bebas multikolinieritas, adalah sebagai berikut:

1) Mempunyai angka tolerance mendekati angka 1 .

2) Mempunyai nilai VIF disekitar angka 1.

\section{b. Uji Asumsi Heteroskedastisitas}

Cara untuk mendeteksinya dapat dilakukan dengan melihat grafik plot antar nilai prediksi variabel terikat (ZPRED) dengan residualnya (SRESID). Deteksi ada tidaknya heteroskedastisitas dapat dilakukan dengan melihat ada tidaknya pola tertentu pada grafik scaterplot antar SRESID dan ZPRED dalam sumbu Y adalah Y yang telah diprediksi, dan sumbu $\mathrm{X}$ adalah residual (Y.Pred Y.sesungguhnya) yang telah distudentized analisisnya.

1) Jika ada pola tertentu seperti titik-titik yang ada dan membentuk pola tertentu yang teratur (bergelombang, melebar, dan kemudian menyempit), maka mengindikasikan terjadi heteroskedastisitas.

2) Jika tidak ada pola yang jelas, serta titiktitik yang menyebar diatas dan dibawah angka nol pada sumbu Y, maka tidak terjadi heteroskedastisitas

\section{c. Uji Normalitas}

Menurut Ghozali (2005:105), "Tujuan dari uji normalitas adalah untuk menguji apakah model regresi variabel terikat dan variabel bebas, keduanya mempunyai distribusi normal 
atau tidak", maka regresi yang baik adalah mempunyai distribusi data yang normal atau mendekati normal.

Cara untuk melihat probability plot yang membandingkan kumulatif dari distribusi normal, distribusi normal akan membentuk satu garis diagonal, apabila distribusi data adalah normal, maka garis yang menggambarkan data sesungguhnya akan mengikuti garis normalnya

\section{Regresi Linier Berganda}

Menurut Sanusi (2011:134), “Regresi linier berganda merupakan perluasan dari regresi linier sederhana, yaitu menambah jumlah variabel bebas yang sebelumnya hanya satu menjadi dua atau lebih variabel bebas". Penelitian ini menggunakan analisis regresi linier berganda, untuk mengetahui ada atau

\section{HASIL DAN PEMBAHASAN}

Penyajian Data

Uji Validitas

Tabel 1. Hasil Ringkasan Uji Validitas tidaknya pengaruh antara kualitas produk dan brand image terhadap keputusan pembelian.

\section{Uji Hipotesis}

a. Uji t

Uji statistik $t$ dilakukan untuk mengetahui pengaruh antara variabel bebas terhadap variabel terikat secara parsial dengan mengasumsikan bahwa variabel lain dianggap constant, (Sanusi, 2003:119).

\section{b. Uji F}

Uji statistik $F$ dilakukan untuk menguji pengaruh variabel bebas terhadap variabel terikat secara simultan, (Sanusi, 2003:119)

Sumber; Data diolah (2015)

\begin{tabular}{|c|c|c|c|}
\hline Variabel/item & r-hitung & r-tabel & Keterangan \\
\hline \multicolumn{4}{|c|}{ Kualitas Produk (X1) } \\
\hline $\mathrm{X} 1.1$ & 0,720 & 0,316 & Valid \\
\hline $\mathrm{X} 1.2$ & 0,770 & 0,316 & Valid \\
\hline $\mathrm{X} 1.3$ & 0,591 & 0,316 & Valid \\
\hline \multicolumn{4}{|c|}{ Brand Image (X2) } \\
\hline $\mathrm{X} 2.1$ & 0,808 & 0,316 & Valid \\
\hline $\mathrm{X} 2.2$ & 0,858 & 0,316 & Valid \\
\hline $\mathrm{X} 2.3$ & 0,702 & 0,316 & Valid \\
\hline \multicolumn{4}{|c|}{ Keputusan Pembelian (Y) } \\
\hline $\mathrm{Y} 1$ & 0,649 & 0,316 & Valid \\
\hline $\mathrm{Y} 2$ & 0,477 & 0,316 & Valid \\
\hline Y3 & 0,686 & 0,316 & Valid \\
\hline Y4 & 0,760 & 0,316 & Valid \\
\hline Y5 & 0,594 & 0,316 & Valid \\
\hline Y6 & 0,524 & 0,316 & Valid \\
\hline
\end{tabular}

Berdasarkan tabel di atas dapat disimpulkan bahwa semu item indikator tersebut dinyatakan valid, karena $\mathrm{r}$ hitung (Corrected Item-Total Correlation) lebih besar dari pada nilai $\mathrm{r}$ tabel yaitu lebih besar dari 0,316 .

\section{Uji Reliabilitas}

Tabel 2. Hasil Ringkasan Uji Reliabilitas

\begin{tabular}{|lcc|}
\hline Variabel & Alpha & Keterangan \\
\hline Kualitas Produk (X1) & 0,461 & Reliabel \\
Brand Image (X2) & 0,694 & Reliabel \\
Keputusan Pembelian (Y) & 0,676 & Reliabel \\
\hline
\end{tabular}


Sumber;

Data

Berdasarkan hasil uji reliabilitas diatas didapat output dari variabel Kualitas Produk (X1), Brand Image (X2), dan Keputusan Pembelian(Y). Berdasarkan output tersebut dapat diketahui nilai reliabilitas (Cronbach's Alpha) tiap variabel

Untuk variabel Kualitas Produk (X1) nilai cronbach's alpha sebesar 0,461, variabel Brand Image (X2) nilai cronbach's alpha sebesar 0,694, variabel Keputusan Pembelian (Y) Nilai cronbach's alpha sebesar 0,676.

Karena nilai ketiga variabel tersebut diatas 0,316 maka dapat disimpulkan bahwa alat ukur dalam penelitian tersebut reliabel.

\section{Analisis Data}

Analisis Statistik Inferensial

\section{Uji Heteroskedastisitas}

diolah

(2015)

\section{Uji Multikolinieritas}

\section{Tabel 3. Hasil Ringkasan Pengujian Multikolinieritas}

\begin{tabular}{|c|c|c|c|}
\hline \multirow{2}{*}{ No } & \multirow{2}{*}{ Variabel } & \multicolumn{2}{|c|}{ Colinearity Statistic } \\
\cline { 3 - 4 } & & Tolerance & VIF \\
\hline 1 & Kualitas Produk & 0,969 & 1.032 \\
2 & Brand Image & 0,969 & 1.032 \\
\hline
\end{tabular}

Hasil uji multikolinieritas dapat dilihat pada tabel 3. Berdasarkan output tersebut dapat diketahui bahwa nilai VIF kurang dari 10 dan nilai tolerance lebih dari 0,1 untuk kedua variabel, maka dapat dsimpulkan bahwa model regresi tidak terjadi masalah multikolinieritas.

Tabel 4. Hasil Uji Heteroskedastisitas

\begin{tabular}{|c|c|c|c|c|c|c|c|}
\hline \multirow[b]{2}{*}{ Model } & \multicolumn{2}{|c|}{ Unstandardized Coefficients } & \multirow{2}{*}{$\begin{array}{c}\begin{array}{c}\text { Standardized } \\
\text { Coefficients }\end{array} \\
\text { Beta }\end{array}$} & \multirow[b]{2}{*}{$\mathrm{T}$} & \multirow[b]{2}{*}{ Sig. } & \multicolumn{2}{|c|}{$\begin{array}{l}\text { Colinearity } \\
\text { Statistics }\end{array}$} \\
\hline & B & Std. Error & & & & Tolerance & VIF \\
\hline 1 (Constant) & 13.798 & 4.083 & & 3.379 & .002 & & \\
\hline Kualitas Produk (X1) & -.261 & .308 & -.126 & -.850 & .401 & .969 & 1.032 \\
\hline Brand Image (X2) & .689 & .234 & .438 & 2.942 & .006 & .969 & 1.032 \\
\hline
\end{tabular}

Dapat diketahui bahwa nilai signifikansi untuk kualitas produk sebesar 0,401, dan brand image sebesar 0,006, karena nilai signifikansi lebih dari 0,05, maka dapat disimpulkan bahwa pada model regresi tidak terjadi masalah heteroskedastisitas.

\section{Gambar 1 Grafik Scatterplot}

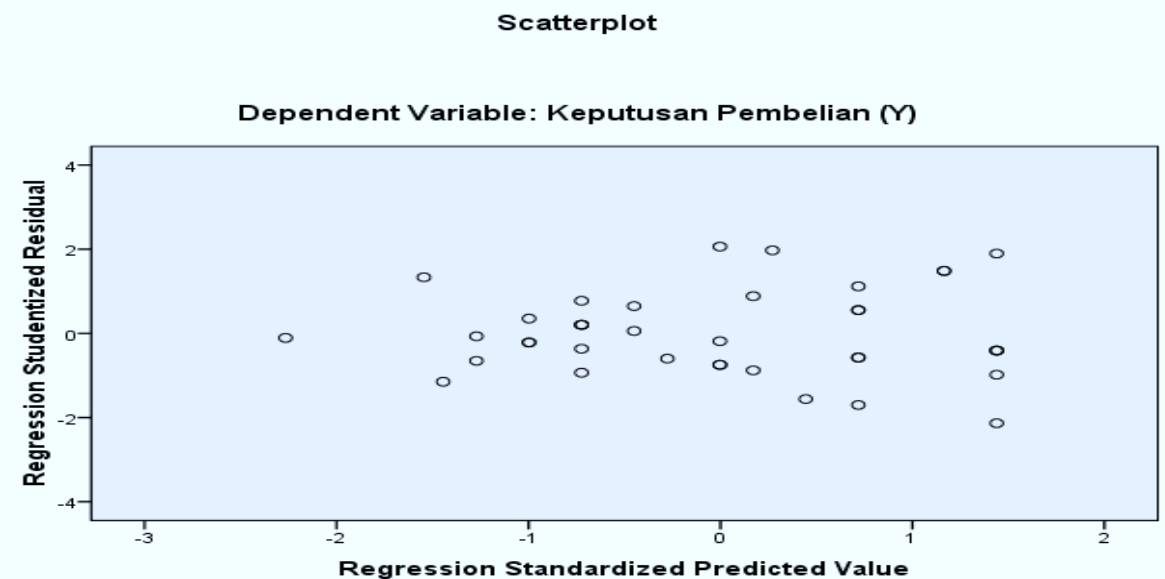


Sumber; Data diolah (2015)

\section{Uji Normalitas}

Gambar 2. Uji Normalitas

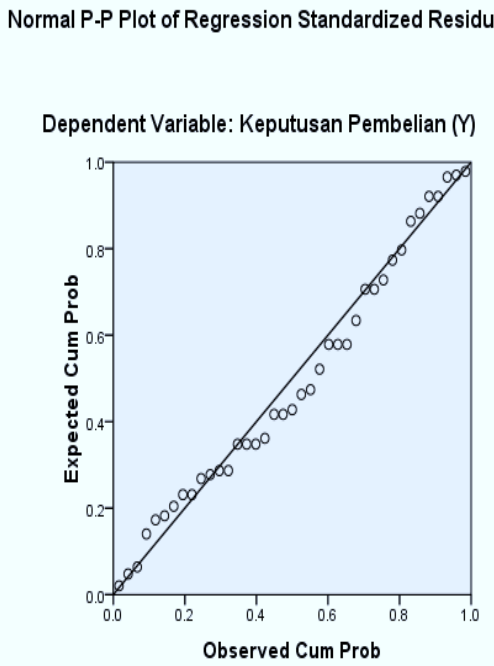

Sumber; Data diolah (2015)

Berdasarkan gambar 7 dapat dilihat bahwa grafik normal probabilyti plot of regression standardized menunjukan pola grafik yang normal. Hal ini terlihat dari titik-titik yang menyebar di sekitar garis diagonal dan penyebarannya mengikuti garis diagonal, maka dapat disimpulkan bahwa model regresi layak dipakai karena memenuhi asumsi normalitas.
Berdasarkan gambar pada grafik dapat diketahui bahwa titik-titik menyebar dengan pola yang tidak jelas di atas dan di bawah angka 0 pada subu $\mathrm{Y}$, maka dapat disimpulkan bahwa tidak terjadi masalah heteroskedastisitas pada model regresi.

\section{Hasil Analisis Regresi Linier Berganda}

Sumber; Data diolah (2015)

\begin{tabular}{|l|l|l|}
\hline Variabel bebas & Koefisien regresi & Sig. T \\
\hline Konstanta regresi & 13,789 & 0,002 \\
Kualitas Produk & $-0,261$ & 0,401 \\
Brand Image & 0,689 & 0,006 \\
\hline Konstanta & $: 13,798$ \\
Multiple R & $: 0,477$ & \\
R Square & $: 0,227$ & \\
F & $: 5,290$ & \\
Sig. F & $: 0,010$ & \\
\hline
\end{tabular}

Persamaan regresi berganda tersebut dijelaskan sebagai berikut:

a. Konstanta sebesar 13,789; artinya jika kualitas produk dan brand image nilainya 0 , maka keputusan pembelian nilainya sebesar 13,789 .

b. Koefisien regresi Kualitas Produk sebesar 0,261 ; artinya jika kualitas produk mengalami kenaikan satu satuan, maka keputusan pembelian akan mengalami penurunanan sebesar -0,261 satuan dengan asumsi variabel independen lainnya bernilai tetap.

c. Koefisien regresi variabel Brand Image sebesar 0,689; artinya jika brand image mengalami kenaikan satu satuan, maka keputusan pembelian mengalami peningkatan sebesar 0,689 satuan dengan asumsi variabel independen lainnya bernilai tetap. 


\section{Pengujian Hipotesis}

Uji t

Tabel 5. Perbandingan $t$ hitung dan $t$ tabel $\alpha=5 \%$

\begin{tabular}{|lccc|}
\hline $\begin{array}{l}\text { Variabel } \\
\text { Ket. }\end{array}$ & t hitung & t tabel & Sig. \\
\hline X1 & $-0,850$ & 2,026 & 0,401 \\
Tidak Sig & & & \\
X2 & 2,942 & 2,026 & 0,006 \\
Sig & & & \\
\hline
\end{tabular}

Sumber; Data diolah (2015)

(1) Nilai t hitung pada variabel Kualitas Produk (X1) adalah sebesar -0,850 dengan tingkat signifikansi 0,401 , karena nilai $\mathrm{t}$ hitung lebih kecil dari t tabel $(-0,850<$ 2,026 ), dengan nilai signifikansi 0,401 lebih besar dari 0,05, maka H1 ditolak dan $\mathrm{H}$ diterima.

Hipotesis 1 : Kualitas Produk secara parsial tidak berpengaruh signifikan terhadap keputusan pembelian.
(2) Nilai t hitung pada variabel Brand Image (X2) adalah sebesar 2,942 dengan tingkat signifikansi 0,006, karena nilai t hitung lebih besar dari t tabel $(2,942>2,026)$, dengan nilai signifikansi 0,006 lebih kecil dari 0,05 , maka $\mathrm{H} 2$ diterima dan $\mathrm{H} 0$ ditolak.

Hipotesis 2 : Brand Image secara parsial berpengaruh tidak signifikan terhadap keputusan pembelian.

\section{Uji F}

Hasil Uji f

\begin{tabular}{|c|c|c|c|c|c|}
\hline \multicolumn{6}{|c|}{ Tabel 6. ANOVA } \\
\hline Model & Sum of Squares & Df & Mean Square & $\mathbf{F}$ & Sig. \\
\hline 1 Regression & 34.678 & 2 & 17.339 & 5.290 & $.010^{\mathrm{a}}$ \\
\hline Residual & 117.989 & 36 & 3.277 & & \\
\hline Total & 152.667 & 38 & & & \\
\hline \multicolumn{5}{|c|}{ a. Predictors: (Constant), Brand Image (X2), Kualitas Produk (X1) } & \\
\hline \multicolumn{5}{|c|}{ b. Dependent Variable: Keputusan Pembelian (Y) } & \\
\hline
\end{tabular}

Sumber; Data diolah (2015)

Berdasarkan tabel 23 didapatkan nilai $\mathrm{F}$ hitung > F tabel $(5,290>3,259)$, karena $F$ hitung lebih besar dari $\mathrm{F}$ tabel, maka $\mathrm{H0}$ ditolak , artinya variabel kualitas produk dan brand image secara bersama-sama (simultan), berpengaruh terhadap keputusan pembelian produk sepatu Converse. Hipotesis 3: Variabel Kualitas Produk dan Brand Image secara bersama - sama berpengaruh terhadap keputusan pembelian

\section{Analisis Koefisien Determinasi (Adjusted R )}

Tabel 7. Analisis Koefisien Determinasi

\begin{tabular}{|l|r|r|r|r|}
\hline Model & R & R Square & Adjusted R Square & Std. Error of the Estimate \\
\hline 1 & $.477^{\mathrm{a}}$ & .227 & .184 & 1.810 \\
\hline
\end{tabular}




\begin{tabular}{|l|c|r|r|r|}
\hline Model & R & R Square & Adjusted R Square & Std. Error of the Estimate \\
\hline 1 & $.477^{\mathrm{a}}$ & .227 & .184 & 1.810 \\
\hline
\end{tabular}

a. Predictors: (Constant), Brand Image (X2), Kualitas Produk (X1)

Sumber; Data diolah (2015)

Berdasarkan output diperoleh angka $R$ Square sebesar 0,227 atau $(22,7 \%)$, hal ini menunjukkan bahwa persentase sumbangan pengaruh variabel independen, yaitu kualitas produk dan brand image terhadap variabel keputusan pembelian sebesar $22,7 \%$, atau variasi variabel bebas yang digunakan dalam model mampu menjelaskan sebesar 22,7\% variasi variabel dependen. Sedangkan sisanya dipengaruhi variabel lain yang tidak dimasukkan dalam model penelitian ini.

\section{Pembahasan Hasil Penelitian}

Berdasarkan hasil penelitian,variabel kualitas produk secara parsial tidak berpengaruh terhadap keputusan pembelian, hal ini disebabkan karena faktor usia responden (Mahasiswa) pada penelitian ini yang tergolong masih muda dan cenderung lebih mengutamakan trends dibandingkan dengan kualitas. Maka hal ini tidak sesuai dengan teori yang di kemukakan oleh Sutisna (2002:26), "Pemahaman konsumen tentang kualitas produk dapat di jadikan dasar terhadap proses keputusan pembelian konsumen", dan hal ini juga menunjukkan hasil yang berbeda dari penelitian-penelitian sebelumnya yang dilakukan oleh Lyonita dan Budiastuti, (2012), tentang "Analisis Pengaruh Brand Image dan Kualitas Produk Terhadap Keputusan Pembelian yang Berdampak pada Loyalitas Konsumen pada PT.Telkom Jakarta Selatan (Produk Speedy)", dan Moly (2014), tentang "Pengaruh Citra Merek dan Kualitas Produk Terhadap Keputusan Pembelian Handphone Nokia (Studi kasus Toko Mars Cell Klandasan, Balikpapan)", dimana hasil dari penelitianpenelitian sebelumnya variabel brand image dan kualitas produk secara parsial berpengaruh terhadap keputusan pembelian konsumen. Sedangkan hasil pada penelitian ini, hanya variabel brand image saja secara parsial yang berpengaruh terhadap keputusan pembelian, hal ini disebabkan karena produk sepatu merek Converse memiliki brand image yang baik yang merupakan faktor paling penting dan dominan bagi konsumen khususnya para mahasiswa pengguna produk sepatu Converse di Fakultas Ilmu Sosial dan Ilmu Politik Universitas Merdeka Malang dalam melakukan keputusan pembelian, dan brand image yang dikelola dengan baik akan menghasilkan konsekuensi yang positif, meliputi:

1. Meningkatkan pemahaman terhadap aspek-aspek perilaku konsumen dalam mengambil keputusan Pembelian,

2. Memperkaya orientasi konsumsi tehadap hal-hal yang bersifat simbolis lebih dari fungsi-fungsi produk.

3. Meningkatkan kepercayaan konsumen terhadap produk, meningkatkan keunggulan bersaing berkelanjutan, mengingat inovasi teknologi sangat mudah untuk ditiru oleh pesaing

Hal ini sesuai dengan teori yang di kemukakan oleh Setiyadi (2003:180), "Konsumen yang memiliki citra yang positif terhadap suatu merek, akan lebih memungkinkan untuk melakukan pembelian", dan Wicaksono (2007:29), "Pentingnya pengembangan citra merek (brand image) dalam keputusan Pembelian". dimana konsumen beranggapan bahwa produk dengan merek yang terkenal di pasaran lebih bagus dan berkualitas dibandingkan dengan produk dengan merek yang kurang populer di pasaran, hal ini disebabkan karena merek yang populer di pasaran memberikan informasi yang lengkap dibandingkan dengan merek yang cenderung tertinggal di pasaran, maka dengan adanya merek konsumen dapat dengan mudah untuk membedakan karakteristik dari tiap-tiap produk yang bermunculan di pasaran.

Berdasarkan hasil penelitian, variabel kualitas produk dan brand image secara bersama-sama (simultan), berpengaruh terhadap keputusan pembelian, hal ini disebabkan karena dengan adanya kualitas yang terjamin dan brand image yang melekat pada produk sepatu Merek Converse, dapat mempengaruhi konsumen khususnya mahasiswa FISIP Unmer Malang dalam melakukan keputusan pembelian. Hal ini menunjukkan hasil yang sama dari penelitian 
sebelumnya yang dilalukan oleh Moly (2014), tentang "Pengaruh Citra Merk dan Kualitas Prroduk terhadap keputusan pembelian Handphone Nokia (Studi Kasus Toko Mars Cell Klandasan, Balikpapan), dimana hasil dari penelitian sebelumnya variabel citra merek dan kualitas produk secara bersama-sama (simultan), berpengaruh terhadap keputusan pembelian konsumen.

\section{KESIMPULAN DAN SARAN \\ Kesimpulan}

1. Variabel kualitas produk tidak berpengaruh terhadap variabel keputusan pembelian pada produk sepatu merek Converse.

2. Variabel brand image berpengaruh terhadap variabel keputusan pembelian pada produk sepatu merek Converse.

3. Variabel kualitas produk dan brand image berpengaruh terhadap variabel keputusan pembelian pada produk sepatu merek Converse

\section{Saran}

1. Berhubung hasil dari penelitian menunjukkan bahwa secara parsial variabel kualitas produk tidak berpengaruh terhadap keputusan pembelian konsumen, melainkan variabel brand image yang memiliki pengaruh terhadap keputusan pembelian konsumen pada produk sepatu merek Converse, namun secara bersama-sama (simultan) hasil penelitian menunjukkan bahwa kedua variabel independen yaitu kualitas produk dan brand image berpengaruh $22,7 \%$ terhadap variabel keputusan pembelian (dependen), hal ini perlu diperhatikan oleh Inc. Converse selaku produsen produk sepatu Converse, karena ketika melakukan pembelian, konsumen tidak terlalu terpengaruh oleh variabel kualitas produk tetapi mereka terpengaruh oleh variabel brand image dalam penelitian ini.

2. Faktor harga, desain produk, brand equity maupun faktor-faktor lain yang mungkin bisa dijadikan refrensi bagi penelitian selanjutnya.

3. Selain menambah variabel independen yang yang memberikan kontribusi terhadap keputusan pembelian, diharapkan penelitian selanjutnya menggunakan metode penelitian yang berbeda untuk membandingkan antara metode penelitian satu dengan metode penelitian lainnya

\section{DAFTAR PUSTAKA}

Aaker, David, A. dan Alexander, L. Biel, 2009, Brand Equity and Advertising: Advertising Role In Building Strong Brand, Lawrence Erlbaum Associates, Inc.,Hillsdale.

Adam, E. E, dan Ronald, J. Ebert, 1992, Productions and Operations Management, New Jersey, Prentice Hall.

Amirullah, 2002, Perilaku Konsumen, Edisi Pertama, Medpress, Yogyakarta.

Arikunto, Suharsimi, 2006, Prosedur Penelitian: Suatu Pendekatan Praktek, Edisi Revisi, PT. Rineka Cipta, Jakarta.

Boyd, Harper, W. Ovrille, C. Larreche, JeanClaude, Mullin, John, W., 2005, Manajemen Pemasaran, Edisi Kedua, Erlangga, Jakarta.

Alma, Buchori, 2005, Manajemen Pemasaran dan Pemasaran Jasa, Alpa Beta, Bandung.

Ferdinand, A. 2000, Struktural Equition Modeling dalam Penelitian Manajemen, Badan Penerbit Universitas Diponegoro, Semarang.

Ghozali, Imam, 2002, Aplikasi Analisis Multivariate Dengan Program SPSS, Badan Penerbit Universitas Diponegoro, Semarang.

Goetsch, D. L, dan Stanley, B. Davis, 2002, Manajemen Mutu Total, Alih Bahasa; Benjamin Molan, Penyunting Wandansari Mardiarti, Edisi Kedua, Jilid 2, PT. Prenhallindo, Jakarta.

Hasan, M. Iqbal, 2002, Pokok-Pokok Materi Metodologi Penelitian dan Aplikasinya, Ghalia Indonesia, Bogor.

Indrianto, Nur, dan Supomo, Bambang, 2002, Metodologi Bisnis Untuk Akutansi \& Manajemen, BPFE, Yogyakarta.

Kotler, Philip, dan Amstrong, Gary, 1995, Dasar-Dasar Pemasaran, Intermedia, Jakarta.

2001, Prinsip-Prinsip Manajemen, Jilid I, Edisi Kedelapan, Alih Bahasa Oleh Damos Sihombing, MBA., Erlangga, Jakarta.

,Kevin, Lane, Keller, 2009, Manajemen Pemasaran, Dialih Bahasakan Oleh Bob 
Sabran, Edisi Ketiga Belas, Erlangga, Jakarta. ,1997, Manajemen Pemasaran: Analisis, Perencanaan, Implementasi, dan Kontrol, Jilid I, Edisi Kesembilan, PT. Prenhallindo, Jakarta.

,1997, Manajemen Pemasaran: Analisis, Perencanaan, Implementasi, dan Kontrol, Jilid I, Ter. Jaka Wasana, Erlangga, Jakarta. ,2001, Manajemen Pemasaran, Edisi 9, PT. Prenhallindo, Jakarta. ,2002, Manajemen Pemasaran, Ter. Benjamin, Molan, PT. Intan Sejati, Klaten. ,2005, Manajemen Pemasaran, Jilid I dan II, PT. Indeks Kelompok Gramedia, Jakarta.

Prawirosentono, Suyadi, 2004, Manajemen Mutu Terpadu, Bumi Aksara, Jakarta.

Radiosunu, 2001, Manajemen Pemasaran; Suatu Pendekatan Analisis, Edisi Kedua, Universitas Gajah Mada, Yogyakarta.

Rangkuti, Freddy, 2002, The Power Of Brand, PT. Gramedia Pustaka Utama, Jakarta.

Sanusi, Anwar, 2011, Metodologi Penelitian Bisnis, Salemba Empat, Jakarta.

Schiffman dan Kanuk, 2004, Perilaku Konsumen, Edisi 7, Prentice Hall, Jakarta.

Setiyadi, Nugroho, J. 2003, Perilaku Konsumen, Konsep dan Implikasi untuk Strategi Penelitian Pemasaran, Prenada Media, Jakarta.

Simamora, Bilson, 2001, Memenangkan Pasar dengan Pemasaran Efektif dan Profitabel, Penerbit PT. Gramedia, Jakarta. ,2011, Riset Pemasan, PT. Gramedia Pustaka Utama, Jakarta.

Stanton, William, J, dan Y. Lamarto, 1994, Prinsip-Prinsip Pemasaran, Jilid I, Erlangga, Jakarta.

Sugiyono, 2006, Metodologi Penelitian Kuantitatif Kualitatif dan $R \& D$, Alfa Beta, Bandung.
Kuantitatif Kualitatif dan R \& D, Alfa Beta, Bandung. 2010, Metodologi Penelitian Kuantitatif Kualitatif dan R \& D, Alfa Beta, Bandung.

2011, Metodologi Penelitian Kuantitatif Kualitatif dan R \& D, Alfa Beta, Bandung.

Sutisna, 2002, Perilaku Konsumen dan Strategi Pemasaran, Rosdakarya, Bandung.

Swastha, Basu, 2002, Manajemen Pemasaran, Edisi Kedua, Cetakan Kedelapan, Liberty, Jakarta.

Tjiptono, Fandy, 2002, Strategi Pemasaran, Andi Offset, Yogyakarta. 1999, Strategi Pemasaran, Andi Offset, Yogyakarta. ,2005, Pemasaran Jasa, Bayu Media Publishing, Malang.

Umar, Husen, 2003, Metode Penelitian: Aplikasi dalam Pemasaran, Gramedia Pustaka Utama, Jakarta.

Vranesevic, Tihomir, 2003, The Effect Of The Brand On Perceived Quality Of Food Product, British Food Journal, Vol.105, No.11,P.811-825. 